\title{
Formation of Integration Communications at the Enterprises: Experience of Foreign Countries and Directions of Development in the Republic of Belarus
}

\author{
Galina Yaheva \\ Department of Economic Theory and Marketing \\ Vitebsk State Technological University \\ Vitebsk, Republic of Belarus \\ gala-ya@list.ru
}

\author{
Yulia Vailunova \\ Department of Economic Theory and Marketing \\ Vitebsk State Technological University \\ Vitebsk, Republic of Belarus \\ Yulia_KG@tut.by
}

\begin{abstract}
The development of methods of formation of integration communications at the enterprises of the Republic of Belarus taking into account foreign experience is the purpose of this article. Theoretical foundations of integration communications are considered. Classification of integration communications by the directions is developed: depending on the subject of interaction; depending on the type of relationship; depending on the direction of interaction. The analysis foreign experience of development of integration processes in enterprises is carried out, which showed that the creation of clusters is one of the ways of increasing the efficiency and competitiveness of enterprises. The comparative analysis of various integration structures is carried out. Advantages of holdings and clusters are revealed. Instruments of support of development of cluster structures in foreign countries are considered. The mechanism of development of integration at the enterprises of Republic of Belarus is offered, it includes the directions of formation of integration communications in the sphere of science and education; in the scientific and technical sphere; in marketing.
\end{abstract}

Keywords—cluster, holding, competitiveness, integration, integration communication.

\section{INTRODUCTION}

The challenges of globalization and the growing influence of institutional environment on business activities, as well as the related increased competition in domestic and foreign markets, actualize the problem of improving the competitiveness of enterprises.

Integration communication can be a competitive advantage of business entities in the context of globalization, acute competition in the market. Companies can increase their efficiency and competitiveness, developing integration communication, which it is confirmed by foreign experience.

After analyzing the experience of the development of integration network communication in foreign countries, it can be concluded that the increase in the competitiveness of the economies of advanced countries is due to: improving the quality of resources through the implementation of joint investment programs in the technical development of suppliers, education, infrastructure; active innovation policy due to the rapid exchange of information and the diffusion of innovations between the subjects of integration, thanks to the joint funding of research and the formation of network links and cooperation between them; growth of investment activity by attracting foreign investment into the integration structure and the formation of international cooperation of stakeholders. However, the methods of integration at the enterprises used in countries with developed market relations, can not be completely transferred to the conditions of the Republic of Belarus due to the specific institutional environment. The methods of formation and development of integration processes at the enterprises, taking into account the economic model of the Republic of Belarus and the institutional environment must be developed. This is the relevance of the topic.

Theoretical foundations of integration communications are developed in the writings by foreign authors, e.g. S. B. Avdasheva, V. A. Abrosimov, A. A. Bogdanov, R. Coase, V. Leontiev, D. S. Mill, D. Ricardo, M. V. Senin, A. G. Spencer, O. Williamson, Y. V. Shishkov, K. Arrow, etc.

The problem of increase of competitiveness in terms of integration has been developed in the writings of modern Russian scientists such as: L. I. Abalkin, G. L. Azoev, G. L. Bagiev, Y. Winslow, G. B. Kleiner, N. D. Kolesov, V. L. Makarov, A. G. Movsesyan, R. A. Fatkhutdinov, A. Y. Yudanov, etc.

The development of methods of formation of integration communications at the enterprises of the Republic of Belarus taking into account foreign experience is the purpose of this article. To achieve this objective, there is the need to: 1 . determine the essence and types of integration communications at the enterprise; 2. consider foreign experience of development of integration communications at the enterprises; 3 . develop of directions of integration communications at the enterprises of the Republic of Belarus.

\section{METHODS}

The main research methods are logical-deductive, analysis and synthesis, statistical, ascent from the abstract to the concrete, etc. 


\section{MAIN PART}

The essence and types of integration communications in the enterprise

The main tendencies of environment influencing integration are:

- acceleration, dynamic of economic processes;

- increased international competition;

- expansion of the international specialization and cooperation of production;

- development of information and communication technologies (which contributes to the establishment of linkages and network cooperation).

In economics, the essential characteristics of the integration of economic entities are treated with different positions, so that there are the following aspects of this concept:

- higher extent of cooperation when organic coherence in implementation of reproduction processes of the separate parties is reached (I. Sukhanova) [1, P. 29];

- the integration increase accompanied with increase in the sizes, concentration frequent diversification and establishment of new more diverse, less rigid communications in large industrial and commercial complexes where communications from external become internal, more actively adjustable; secondly, the establishment of new communications between economic units (E. Gerstein) [2, P. 86-94];

- organizational, economic and legal. (Ignatyev N. M.) [3, P. 102].

Suppliers, resellers, customers, regional administrations and others are significant actors of the external environment which have impact on competitiveness of the enterprises. The system of partner integration communications is formed owing to the relations with them and provides competitive advantages to the enterprises.

Integration communications at the enterprise is an association, creation of communications, development of relationship between business entities (stakeholders) which is shown in various connection of their resources for realization of the purposes of effective joint cooperation and assumes voluntariness of this process based on business ethics.

The following levels of integration communications of economic entities are offered based on the concept of value chain.

1. Integration levels for extension of the value chain:

- at the enterprise level (formation of internal corporate relations, internal value chain);

- $\quad$ at the industry level (integration of related businesses in technological chains);

- $\quad$ at the interindustry level (identification of new needs and new areas of activity and the formation of intersectoral communications).

2. Integration levels for development of the value chain:

- production - education;
- production - science;

- production - consulting, marketing;

- production - the state.

Integration at various levels and in its different types is shown in the form of integration communications between her stakeholders.

The classification of integration communications includes the following areas.

The first direction - depending on the subject of interaction, vertical and horizontal communications can be distinguished.

Vertical integration communications are the establishment of interaction with the supplier enterprise (integration down) or the consumer enterprise (integration up) of the products or services of this enterprise. This type of integration can also include the integration of production and the network of sales enterprises, which means that the communications between adjacent links in the technological and distribution chains (value chains) are strengthened.

Horizontal integration communication mean the establishment of integration links with enterprises producing similar or related products.

The second direction-depending on the type of relationship, we will distinguish formal (business, official) and informal (personal unofficial) communications.

Relationships between integration subjects that are based on their individual and personal qualities and are expressed in the assessment of these qualities reflect the presence of informal integration communications.

Formal integration communications are relationships between actors to achieve common goals within some form of integration based on established standards, norms and responsibilities.

Informal and formal communications create the basis for network cooperation, are interconnected, but in the context of globalization and digitalization, it is necessary to develop informal vertical communications and informal horizontal communications.

Analyzing the institutional framework of interaction between actors, most institutionalist scientists, among which, A. Berli [ 4], T. Veblen [5], R. Coase [6, 7], J. Mitchell [8], A. Nove [9] and others point out the advantage of informal relationships between agents that they promote decrease in transactional expenses.

The third direction of integration communications classification is depending on the direction of interaction: communication with competitors (competition concept), cooperation communication (cooperation concept), combining the concept of co-competition (coopetition concept).

The coopetition concept was developed by Brandenburger Adam M. and Nalebuff Barry J. in the middle of the 1990 [10, P. 57-71; 11]. If the earlier competition and cooperation were seen as two opposing sides, but now the company's success is often determined by its ability to simultaneously realize how competitive strategies, and strategies for cooperation [12, P. 110-141]. 


\section{Foreign experience of development of integration in enterprises}

The most important characteristic of modern world economy is the development of integration communications. Different forms of integration structures are created in foreign countries. There are about 40 thousand large integration structures in the world in 150 countries; they account for more than $50 \%$ of world trade, $50 \%$ of industrial production in the world, $75 \%$ of intellectual property rights. Enterprise associations of the USA and Germany, "syudana" and to "keyreets" of Japan, "chebola" of South Korea are of special interest [13, P. 23].

In the economies of developed countries (USA, Japan, Germany, Switzerland and others), large integration structures play a significant role: they control more than $1 / 3$ of the industrial production of their countries, more than $1 / 2$ of foreign trade, more than 3/4 of patents and licenses for high technologies and «know-how» [14, P. 7].

Network cooperation is the basis for the development of integration communications and is actively developing between stakeholders in foreign countries (Table 1).

Clusters and holdings have received the greatest distribution in the world. Comparative analysis of different integration structures are shown in Table 2.

TABLE I. Network Communications In TeChNological Platforms Of The European Countries [15]

\begin{tabular}{|l|c|}
\hline \multicolumn{1}{|c|}{ Types of network communications } & Countries \\
\hline $\begin{array}{l}\text { «Science-science» communication (implementation of joint projects of research } \\
\text { centers) }\end{array}$ & $\begin{array}{c}\text { Belgium, Spain, Norway, France, } \\
\text { Switzerland }\end{array}$ \\
\hline «Science-industry» communication (implementation of public-private projects) & $\begin{array}{c}\text { Belgium, Germany, Denmark, Italy, Norway, } \\
\text { Poland, Portugal, France, Finland }\end{array}$ \\
\hline «Industry-industry» communication (promotion of joint industry projects) & Belgium, Denmark, Spain, Poland, Portugal \\
\hline «Smart» specialization of clusters & $\begin{array}{c}\text { Austria, Belgium, France, Germany, Ireland, } \\
\text { Spain, Turkey, Finland, Czech Republic, } \\
\text { Estonia }\end{array}$ \\
\hline
\end{tabular}

TABLE II. DISTINCTIVE CHARACTERISTICS OF FORMS OF INTEGRATION STRUCTURES $[16,17,18]$

\begin{tabular}{|c|c|c|}
\hline Cluster & «Rigid» holding & «Soft» Holding \\
\hline \multicolumn{3}{|c|}{ Legal status } \\
\hline not & $\begin{array}{l}\text { it is defined by the legislation } \\
\text { (registration is necessary) }\end{array}$ & $\begin{array}{l}\text { it is defined by the legislation } \\
\text { (registration is necessary) }\end{array}$ \\
\hline $\begin{array}{l}\text { in a joint decision, at the initiative of constituent } \\
\text { entities of the cluster }\end{array}$ & $\begin{array}{l}\text { by decision of one management company/owner } \\
\text { of the property of holding participants or a state } \\
\text { body - for state-owned enterprises }\end{array}$ & by an agreed decision of the subjects \\
\hline \multicolumn{3}{|c|}{ Existence of communications } \\
\hline $\begin{array}{c}\text { it is based on horizontal communications } \\
\text { between participants, their independence from } \\
\text { each other }\end{array}$ & $\begin{array}{l}\text { it is based on vertical communications between } \\
\text { participants }\end{array}$ & $\begin{array}{c}\text { it is based on vertical and horizontal } \\
\text { communications, informal communications and } \\
\text { trust }\end{array}$ \\
\hline \multicolumn{3}{|c|}{ Direction of formation of competitiveness } \\
\hline $\begin{array}{c}\text { competitiveness increase production at the price } \\
\text { is due to decrease in expenses } \\
\text { (transactional, logistic, on the maintenance of } \\
\text { management personnel) and discounts to } \\
\text { intermediaries thanks to vertical and horizontal } \\
\text { integration }\end{array}$ & $\begin{array}{l}\text { competitiveness increase } \\
\text { production at the price is due to decrease in } \\
\text { expenses (transactional, logistic, on the contents } \\
\text { management personnel) and discounts to } \\
\text { intermediaries thanks to vertical integration }\end{array}$ & $\begin{array}{c}\text { competitiveness increase } \\
\text { production at the price is due to decrease in } \\
\text { expenses (transactional, logistic, on the } \\
\text { maintenance of management personnel) and } \\
\text { discounts to intermediaries thanks to vertical and } \\
\text { horizontal integration }\end{array}$ \\
\hline \multicolumn{3}{|c|}{ Management and coordination } \\
\hline $\begin{array}{l}\text { creation of collegial coordinating body of a } \\
\text { cluster by its participants, independence of the } \\
\text { coordinating structure }\end{array}$ & $\begin{array}{l}\text { initial existence of management company of } \\
\text { holding or the owner management company } \\
\text { (owner) influences the decisions made by } \\
\text { participants of holding }\end{array}$ & $\begin{array}{l}\text { creation of coordination council and working } \\
\text { groups on formation of network interaction }\end{array}$ \\
\hline \multicolumn{3}{|c|}{ Independence and dynamism } \\
\hline simplicity of an exit from a cluster & $\begin{array}{l}\text { complexity of an exit } \\
\text { subsidiary from holding }\end{array}$ & simplicity of an exit from "soft" holding \\
\hline \multicolumn{3}{|c|}{ Condition of territorial concentration } \\
\hline certainly & doesn't matter & $\begin{array}{l}\text { for holding necessarily, for the networking } \\
\text { doesn't matter }\end{array}$ \\
\hline
\end{tabular}

The advantages of clusters and "soft" holdings are as follows: decrease of transaction costs due to informal connections; activation of scientific research and production of competitive products due to joint research and development programs with soft holding entities; increase in sales volumes, acceleration of turnover due to the creation of supply chains; increase in export indicators due to the implementation of joint marketing programs; increase in the efficiency of participants activities in general due to the synergistic effect.

It is expedient to study foreign experience of support of cluster structures for development of the mechanism of integration communications in Republic of Belarus. The conducted research is revealed the following instruments of development support of cluster structures in foreign countries: 
- direct financing, which accounts for about $50 \%$ of the cost of creating new products and technologies (France, USA, Russia and other countries);

- tax relief for businesses, including an exception of the taxable sums of costs of research and development and writeoff of investments on research and development, the preferential taxation of universities and scientific research institute (Japan);

- legislative support for intellectual property rights and copyright;

- providing loans, including without payment of percent (Sweden);

- target grants for research development (in almost all developed countries);

- creation of introduction innovation funds with possible commercial risk (England, Germany, France, Switzerland, the Netherlands, Russia);

- grants of up to $50 \%$ of costs for the introduction of innovations (Germany);

- decrease in the state taxes for individual inventors and representation of tax privileges (Austria, Germany, USA, Japan, etc.), and also creation of special infrastructure for their support and economic insurance (Japan);

- postponement of payment of duties or exemption from them, if the invention relates to energy savings (Austria);

- free record keeping at the request of individual inventors, patent attorneys free services, exemption from duties (the Netherlands, Germany);

- state programs on decrease in risks and compensation of risk losses (Japan);

- research programs and attracting foreign talented experts, including expedited processing of their visas, presentation of scholarships for training and improvement of living conditions (Japan, USA, Australia) [19].

The following regularities of development of the steady integrated structures can be identified after analyzing their process of formation in the industry in foreign countries:

1. in foreign countries, more often in economically developed countries, mainly "soft" forms of structures are created, and in less developed countries - "hard" structures, which confirms the variety of types of integration structures;

2. development of communications between science and industry in foreign countries based on the creation of technological platforms;

3. the operation of incentive instruments to support cluster structures in economically developed countries;

4. innovation activity within clusters is more active than outside clusters, as evidenced by the experience of foreign countries.

\section{Directions of development of integration communications at the enterprises of Republic of Belarus}

Results of an assessment of level of integration communications at the enterprises of Republic of Belarus, by the technique developed by the author, showed a low level of development of integration communications in the horizontal
(2,3 points from 5$)$, the average level of interaction on a vertical ( 3,15 points from 5 possible).

The following directions of development of integration communications in the factors of competitiveness are proposed: education, innovation and marketing.

Creation of joint structures is offered in the sphere of science and education.

1) Creation of representations of the vertically integrated holding at regional universities through: creation of joint chairs and joint research laboratories is offered. Head of the Department, members of the department, students, employees of the holding should be included in the joint research laboratories. The tasks of the joint research laboratory include: advanced training of the teaching staff of the university and advanced training of scientific workers; increasing the level of training of specialists; strengthening and development of the scientific and intellectual potential of the university; implementation of innovative development programs and contractual scientific developments; strengthening scientific contacts between university staff and research organizations.

2) Creation of corporate training centers in management company of holding together with regional universities.

The corporate training center is a tool for implementing the strategy of training and development of personnel in the company, which is aimed at meeting the company's need for qualified personnel in the long term, it is a form of personnel training in which it is conducted "within the walls" of the organization itself and, mainly, by its own forces.

The differences between the corporate training center and the academic form of study at the university include:

- the predominance of a practical orientation;

- the main form of education is electronic (including distance learning);

- acting as teachers (business trainers) of their staff.

3) Creation of scientific and technical spin-off companies.

The functions of scientific and technical spin-off enterprises include: creating added value through the development of a technological product from scientific results for an individual demand profile; accelerating the final stages of the innovation process; providing an inexpensive and conflict-free channel for commercialization of research results and technology transfer from science to production; ensuring the quality of jobs created; introducing new technologies [20].

Open on the basis of universities, innovative companies allow you to turn research results into high-quality samples of products with higher consumer, technological, technical, economic and other properties than those that exist on the market, as well as provide additional jobs. The management company of holding is offered by the founder of this innovative enterprise.

The recommended organizational form of realization of results of researches and development is foundation of firm with preservation of strong communications with the parental organization, i.e. holding and university.

Network connections within the scientific and technical spin-off of the enterprise are reflected in the production of 
high technology products based on the implementation of the following areas:

- joint implementation of research work;

- joint designing and development of innovative products;

- joint development of innovative goods from processing products;

- $\quad$ improving product design;

- innovative equipment;

- joint development and production of high-tech products.

Creating of a technological platform is offered for a network of cooperation and developments of integration communications in science and technology. The technology platform should unite the efforts of the holding representatives, networking subjects, science and government.

Technological platform objectives are: coordination of research carried out on a competitive stage, including in the framework of technological forecasting system formed, which includes: identification of technology packages, including the production of key technologies that can provide a sustainable competitive on the world market holding; definition of thematic areas of research, fundamental and applied problems, the solution of which is necessary for the formation of appropriate technology packages; assessment of the necessary resource support for research.

A technological platform is a platform where representatives of the integration structure, stakeholders and government officials will gather to discuss issues of development and increase the efficiency of the economy of the region and the country as a whole.

Cooperation in marketing is reflected in the implementation of the following areas:

- use of co-branding, i.e. sharing communication channels several partners to develop the market in which the total effect is greater than the results of using the same channels of each of the partners individually;

- the conducting joint market research foreign markets;

- the development of corporate social responsibility strategy;

- the joint program of market segmentation and product positioning;

- the joint sales promotion programs on the international market, including advertising, sales promotion, conducting trade and industrial fairs;

- the creation of common information networks among participants networking based CRM technology.

Thus, the formation of a strategy of integration communication and mechanisms for its implementation need to be developed to ensure the innovative development of enterprises of the Republic of Belarus.

\section{CONCLUSION}

The development of integration communications will allow to establish such relationship between the enterprises (partners) which will provide long-term convergence of the general objectives of the integrating and integrated enterprises. Theoretical and methodological bases of use of the new resource of innovative development of the economy - integration communications between the subjects of business, as well as between the last and the education sector are developed and presented in this paper will provide a synergistic effect of cooperation.

The proposed directions of formation of integration communications in the Republic of Belarus and the methods for its implementation will be interesting both for business representatives, and for the bodies of state and regional administration, education and marketing centers. Thus, using the foreign experience of development of integration communications and implementation of the proposed methods of integration communications of the Republic of Belarus will allow enterprises to improve competitiveness and efficiency.

\section{REFERENCES}

[1] I. F. Sukhanova, Laws of Laws of development of Russian integration relations in the conditions of market economy": Moscow, 2001.

[2] E. F. Gerstein, Differentiation and integration in the industry: the theory and practice of development, Minsk ,1993.

[3] N. M. Ignatiev, "On the concept of economic integration of business entities", Economic Journal, 2012, (27), pp. 99-104.

[4] A. A. Berle, The 20th Century Capitalist Revolution, New York, Harcourt, Brace, 1954

[5] T. Veblen, The Theory of the Leisure Class,Moscow, 1984.

[6] R. H. Coase, "The nature of the firm", Economica. New Series, 1937, (16), pp. 386-405.

[7] R. H. Coase, The firm, the market, and the law, Moscow, 2007, M.

[8] J. Michael, Enright and Ifor Ffowcs-Williams Enhancing the competitiveness of SMEs in the global economy: strategies and policies, Conference for Ministers responsible for SMEs and Industry Ministers, Bologna, Italy, 2000. URL: http://www.oecd.org/daf/corporate (accessed 10.09.2020).

[9] A. Nove, Economic strategy of communism. The growth and the possibility of the Soviet Union, Ed. : Foreign Literature, 1960.

[10] M. Adam, Brandenburger, \& Barry J. Nalebuff, "The Right Game: Use Game Theory to Shape Strategy", Harvard Business Review, 1995, pp. $57-71$.

[11] M. Adam, Brandenburger, \& Barry J. Nalebuff, "Co-opetition: A Revolutionary Mindset that Combines Competition and Cooperation", 1998.

[12] A. G. Lado, N. G. Boyd, \& S. C. Hanlon, "Competition, Cooperation and the Search for Economic Rents: A Syncretic Model", The Academy of Management Review, 1997, (22), pp. 110-141.

[13] S. S. Sulakshin, E. A. Buyanova, Legal holding a model for Russia, Moscow, 2012

[14] S. B. Shepelev, "FormatiFormation and development of corporate structures of holding type in the conditions of industrial restructuring", Dis. ... Cand. ehkon, Moscow, 2004. URL: http://www.iprras.ru/authoref/aut-shep.pdf (accessed on: 10.09.2020).

[15] OECD Science, Technology and Industry Outlook, 2012, URL: http://www.oecd-ilibrary.org/science-and-technology/oecd-sciencetechnology-and-industry-outlook-2012_sti_outlook-2012-en (accessed 10.09.2020).

[16] D. M. Krupsky, About conditions and opportunities of formation and development of industrial clusters in Republic of Belarus, 2014, URL: economy.gov.by/nfiles/001146_914457_Klaster.pptx (accessed 10.09.2020).

[17] G. A. Yasheva, The cluster approach to improve the competitiveness of enterprises, Vitebsk: Vitebsk state technological university, 2007,. $301 \mathrm{p}$.

[18] G. A. Yasheva, The cluster concept of increasing the competitiveness of enterprises in the context of network cooperation and public-private partnerships, Vitebsk: Vitebsk state technological university, 2010, $373 \mathrm{p}$. 
[19] A. K. Kazantsev, \& I. A. Nikitina, Innovation clusters in regional strategies, Bulletin of St. Petersburg State University, 2011. URL: http://polpoz.ru/umot/kazancev-a-k-d-e-n-professor-spbgu/ (accessed 10.09.2020).

[20] A. I. Pobol, Scientific and technological enterprise in the national innovation system: laws of functioning and development: Dis. ... Cand. ehkon. Sciences, Belarusian State University: Minsk, 2009. 